\title{
ACADEMIC INTEGRITY IN UKRAINIAN UNIVERSITIES: CASE OF ACADEMIC IQ PROJECT IN TNPU
}

\section{Mariya Boyko}

Ternopil Volodymyr Hnatiuk National Pedagogical University, Ternopil, Ukraine https://orcid.org/0000-0002-3864-1044

\section{Oleksandr Dluhopolskyi}

West Ukrainian National University, Ternopil Volodymyr Hnatiuk National Pedagogical University, Ternopil, Ukraine https://orcid.org/0000-0002-2040-8762

\section{CMESTE}

JEL Category: H52, 121, 123

\begin{abstract}
The article is focused on the evaluation of the implementation of the project "Academic IQ" in Ukrainian universities (case of Ternopil Volodymyr Hnatiuk National Pedagogical University). The study analyzes the progress of Ukraine towards improving the quality of higher education both with the help of internal stakeholders and with the help of external donors-partners of educational reforms. Based on the survey of 194 teachers and 1293 TNPU students, it was found that the university is actively working to clarify the law, the institution's policy on academic integrity in the educational process, and technical verification of plagiarism is carried out by software resources, expert verification is carried out by a qualified commission, the principle of blind peer review is implemented. The university also has a transparent system of questionnaires of students about the disciplines they have passed, which enables it to quickly make changes to educational programs. Conclusions emphasize that students are well informed about the procedure of appeals in violation of the rules of academic integrity, teachers and students communicate effectively with each other, and the percentage of classes attended by students during the semester corresponds to high attendance and quality work of the university.
\end{abstract}

Keywords: academic integrity, university, quality assurance, NAQA, TNPU

\section{INTRODUCTION}

Issues of academic integrity, well-known to the educational environment of highly developed

Address of the corresponding author: Oleksandr Dluhopolskyi 琵dlugopolsky77@gmail.com countries, have long been ignored by the Ukrainian scientific and educational community. The reasons for this are quite different - from 
inherited from the Soviet-era practices of educational conformism, "buying positions and awards" to the need to survive in a reduced contingent of students, increasing competition in the market of educational services with minimal budget funding and lack of incentives to improve education. However, with the adoption of the Laws of Ukraine "On Higher Education" in 2014 and "On Education" in 2017, the issue of academic integrity among all education stakeholders has become important. An additional factor in strengthening the institutional capacity of the higher education system in this direction was the establishment of the National Agency for Higher Education Quality Assurance (NAQA) in 2015, with the mission to catalyze positive changes in higher education and culture of its quality (NAQA, 2021; Stukalo, Dluhopolskyi, 2020).

Academic integrity in the direction of strengthening the quality of higher education in Ukraine acquires a special role not only due to the internal motivations of the educational community but also to external stakeholders - international donors who implement "best practices" of world standards of academic integrity in Ukraine. One such project is the Academic Integrity and Quality Initiative - Academic IQ, which aims to bring together the professional community of educators working in secondary and higher education to share experiences and work together to support academic integrity and quality of education (AcademIQ, 2021).

The beginning of this project was preceded by the successful administration by the American Councils of Strengthening Academic Integrity in Ukraine Project, SAIUP (2016-2019) and Seeding Academic Integrity in Secondary School, SAISS (2017-2019). Today, this project is implemented with the assistance of the US Embassy in Ukraine and with the support of the Ministry of Education and Science of Ukraine and the National Agency for Quality Assurance in Higher Education (American Councils, 2021). It involves 60 leading institutions of higher education in Ukraine, including Ternopil Volodymyr Hnatiuk National Pedagogical University (TNPU), which is recognized as the leader in humanities education and the best pedagogical institution of higher education in Ukraine in 2020.

\section{METHODOLOGY}

As part of the Academic IQ project, a survey was conducted on the issues of academic integrity by students and teachers of TNPU (from December $1^{\text {st }}, 2020$, to February $\left.5^{\text {th }}, 2021\right)$. The survey covered 1293 students from different faculties and courses of the university and 194 teachers from different faculties of TNPU. Among the surveyed students, $85 \%$ are women and $15 \%$ are men, and among the surveyed teachers, $73 \%$ are women and $27 \%$ are men.

\section{RESULTS}

The Commission on Academic Integrity, Ethics and Conflict Management, and the Academic Integrity Promotion Group (TNPU, 2021) promote the principles of academic integrity and their implementation in the educational and scientific activities of the university.

Surveys of TNPU students were conducted in the following areas: 1) familiarity with the norms of academic integrity at the university; 2) application of sanctions because of the violation of the norms of academic integrity; 3) monitoring satisfaction with the educational process; 4) learning the basics of academic writing.

The answers to the questions about the problems that TNPU students most often discussed with teachers during the school year were distributed as follows (Fig. 1): $50.1 \%$ noted the question of requirements for written research papers, $44.1 \%$ citation rules and reference rules on sources of information, $43 \%$ problems of plagiarism and cheating, $41.7 \%$ issues of ethics and academic integrity, $35.8 \%$ sanctions in case of plagiarism.

When a student copies from another student during a written task, $44.5 \%$ of TNPU teachers make only oral remarks, while $29.8 \%$ of teachers punish these cases using lower scores. However, when a student submits someone else's written work on his behalf, the sanctions of teachers are much stricter, and thus $-52.2 \%$ do not accept the work.

Only $9 \%$ of university students said that during the entire period of study they had to file a complaint to the teacher or the administration of TNPU due to dissatisfaction with the educational process. 
$35.2 \%$ of students asked teachers for clarification on the criteria for assessing tasks.

When asked how common it is to get extra points for completing additional tasks within the course, almost $54 \%$ of TNPU students answered in the affirmative (Fig. 2).

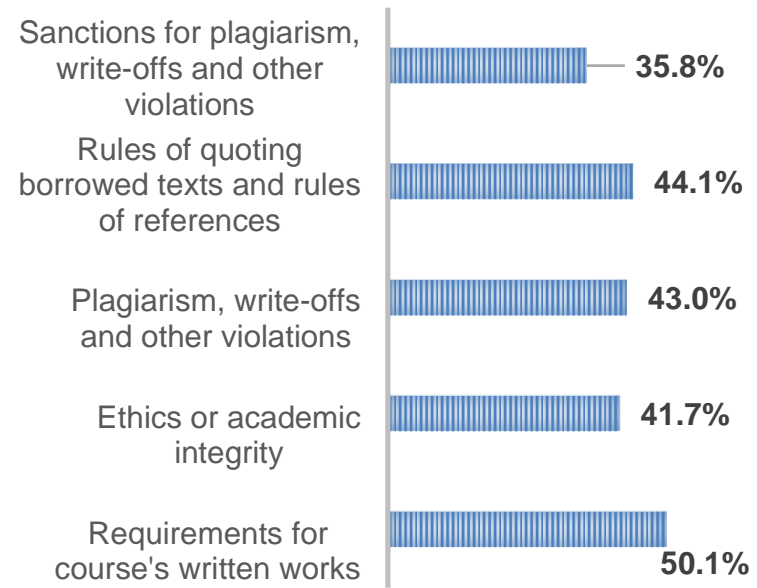

Fig. 1 Top 5 questions TNPU students discussed with academic and teaching staff

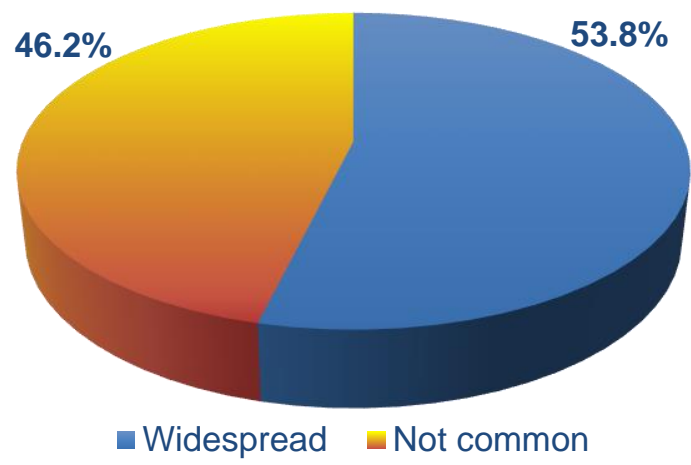

Fig. 2 Possibility to earn extra points for completing additional tasks in TNPU

To ensure the transparency of the student work evaluation process, only $29 \%$ of teachers provide detailed commentary on student work (Fig. 3).

$53 \%$ of students said that they had taken a course or individual topics in academic writing at the university, while $47 \%$ did not remember it.

$72.6 \%$ of surveyed students attended classes online and in classrooms during the semester.

Only $37.3 \%$ of students say that after each discipline they are surveyed about the level of satisfaction with the knowledge gained from it, while $41.2 \%$ of students do not know about such a procedure.

Surveys of TNPU teachers were conducted in the following areas: 1) familiarity with the norms of academic integrity at the university; 2) tolerance to plagiarism; 3) criteria for assessing students; 4) availability of plagiarism detection software.

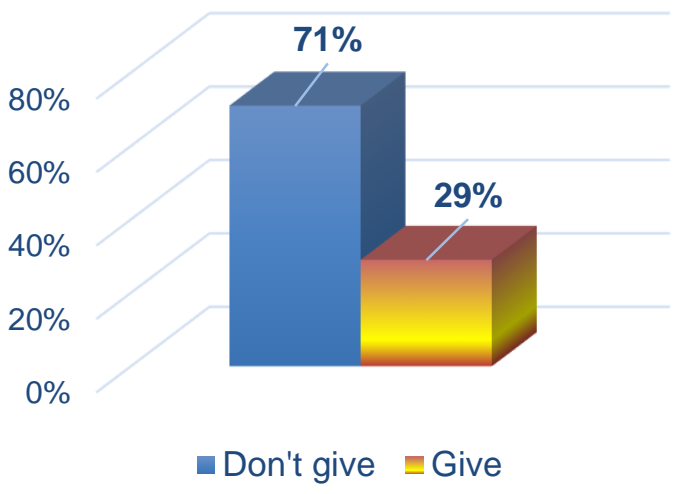

Fig. 3 Do university teachers comment on student work?

Thus, the results of the survey revealed that $82 \%$ of teachers took part in activities related to the clarification of the current legislation and policy of the institution regarding academic integrity. $78.9 \%$ of TNPU teachers understand their role and functions in the mechanisms of counteracting academic dishonesty. $66.1 \%$ have information on sanctions that can be applied to students in case they violate the rules of academic integrity. However, only $39.3 \%$ of respondents note that all university teachers follow a single procedure in case of detection of violations of academic integrity (Fig. 4).

Regarding the availability of plagiarism detection software, $62.6 \%$ of teachers said they had access to it, but only $56.5 \%$ used it to check students' term papers and dissertations.

To the question "In which cases can a teacher not respond to detected plagiarism?" the answers of the respondents were distributed as follows: $44.1 \%$ indicated that only if the amount of plagiarism turned out to be insignificant; $8.5 \%$ - if the student did not know about the sanctions for detected plagiarism; $6.8 \%$ - if the student does not understand the content of plagiarism; $5.1 \%$ - if the student has an excessive workload; $4.5 \%$ - if the 
student does not understand the difficult task and only $5.1 \%$ - would never ignore the detected plagiarism (Fig. 5).

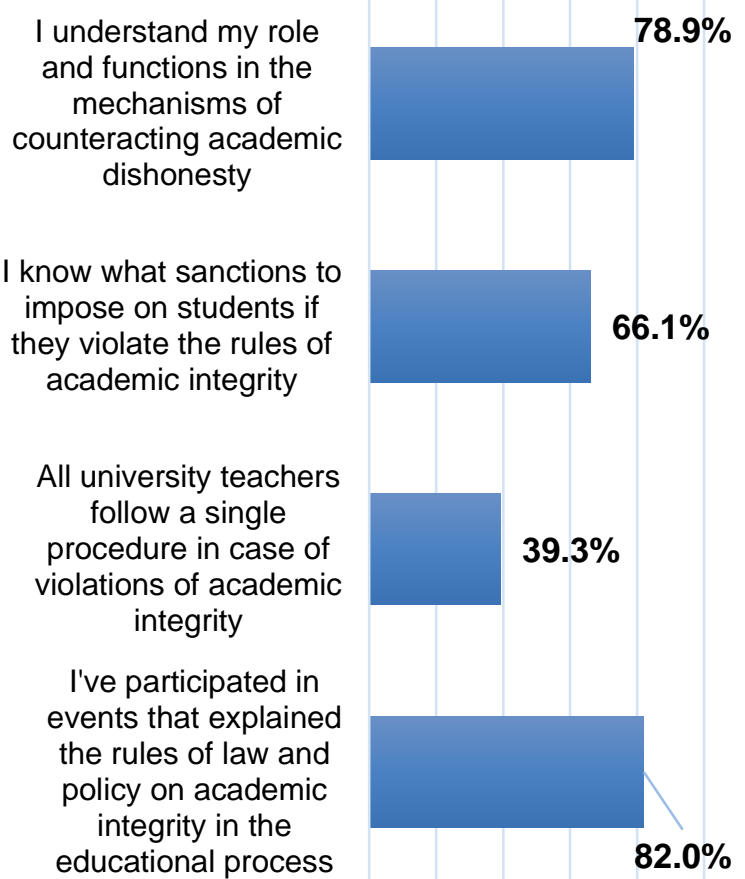

Fig. 4 Awareness of TNPU teachers with the norms of academic integrity

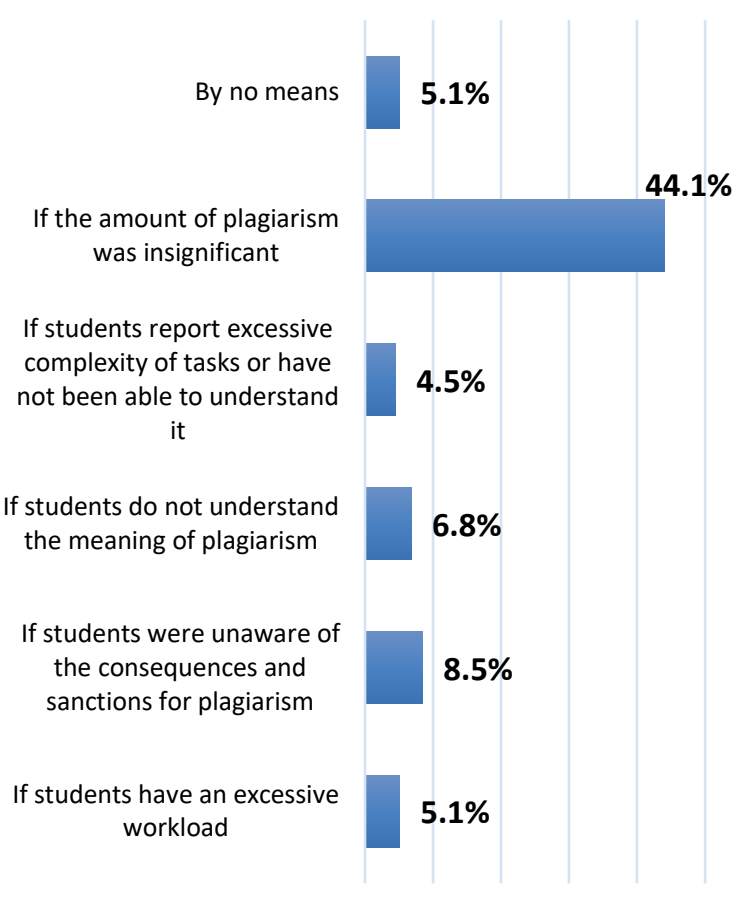

Fig. 5 In what cases can a teacher "close his eyes" to plagiarism?
To the question "What will you do if a student violates the principles of academic integrity in an exam or writing?" the answers of teachers were distributed as follows: $49.2 \%$ will follow the regular university procedures; $41.7 \%$ - do not accept and do not assess the student's work; $33.7 \%$ - will reduce the assessment points, and $8 \%$ indicate the lack of clear procedures and rules for responding to such things.

According to the responses of TNPU teachers, it will not be considered plagiarism when a student copied one sentence from another source for use in his work if (Fig. 6): 1) this sentence is quoted and the author and page of his work are mentioned $(83.1 \%) ; 2$ ) if it is only one sentence, then it is not enough to be considered plagiarism $(16.9 \%) ; 3)$ if this sentence is taken from student's another work even without reference $(14.6 \%)$; 4 ) if several words are replaced even without a reference $(6.2 \%)$.

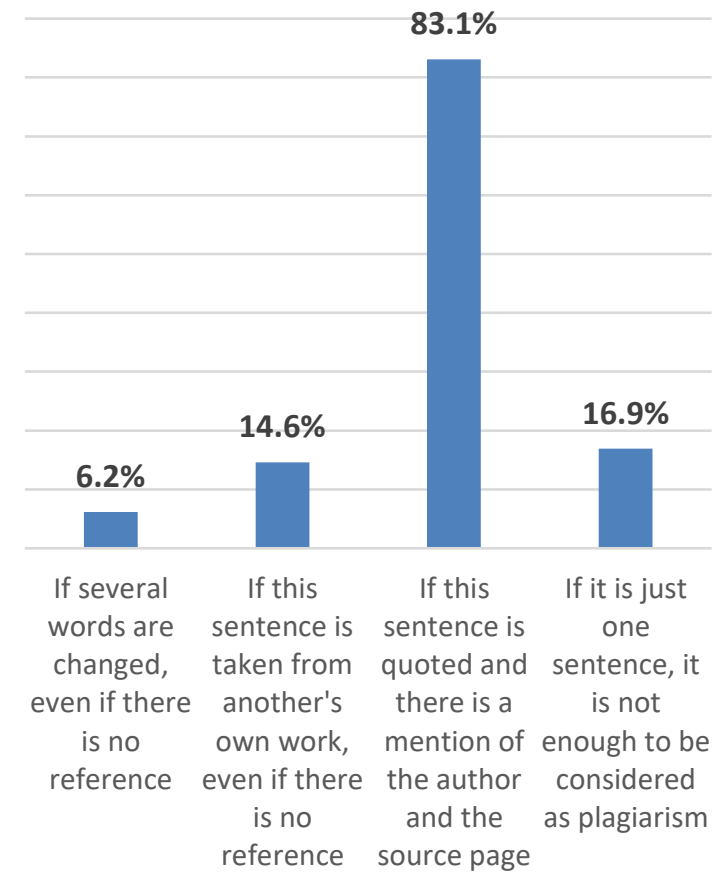

Fig. 6 Under what conditions is it not considered plagiarism for a student to copy one sentence from another source and use it in his work?

As for the criteria for assessing disciplines, mostly university teachers discuss them with students at the beginning of each course $(64 \%)$, while only $36 \%$ of teachers prescribe "rules of the game" in discipline syllabi (Fig. 7). 
$89.5 \%$ of TNPU teachers take into consideration annual surveys on the quality of educational programs, and $95 \%$ note that according to the results of surveys, changes are made to educational programs.

$66.1 \%$ of TNPU teachers have information on where to report violations of the rules of academic integrity by university students.

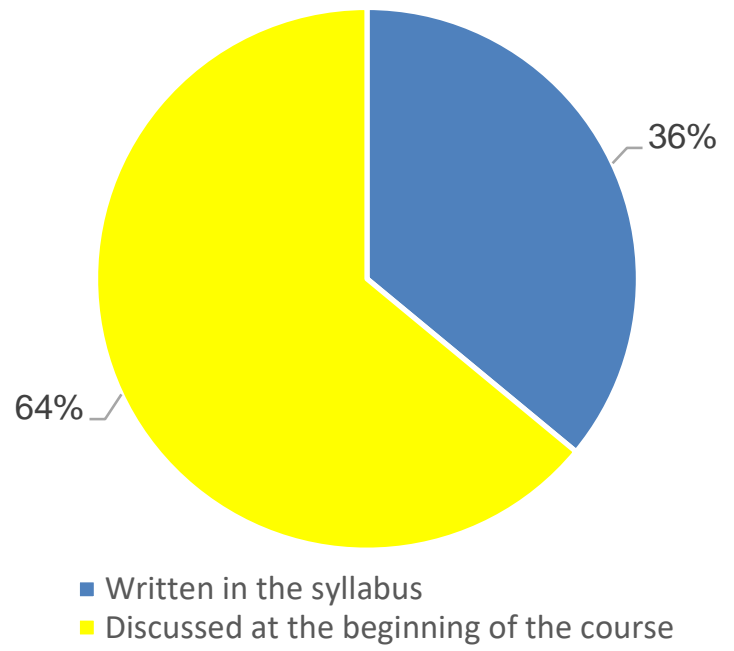

Fig. 7 The source of students' awareness of the general criteria for assessing the discipline?
$74.3 \%$ of teachers consider the workload of TNPU students to be moderate, but only $43.7 \%$ of surveyed students hold a similar opinion. Regarding TNPU teachers' workload, $50.3 \%$ of the staff consider it excessive.

\section{CONCLUSIONS}

In summary, according to the results of the study, TNPU students are most familiar with the requirements for written work in the process of studying courses, with the rules of ethics and principles of academic integrity, rules of citation, references. Regarding the application of sanctions to violators of the principles of academic integrity, most teachers follow the regular procedures currently agreed at the university. TNPU regularly surveys students about their disciplines, and most teachers make changes to educational programs based on student surveys. Students are well informed about the procedure for appeals in violation of the rules of academic integrity. Survey data show that the teacher and the student communicate effectively with each other, and the percentage of classes attended by students (generally online and in classrooms) is $72.6 \%$, which corresponds to a high level of attendance.

\section{WORKS CITED}

AcademIQ (2021). About Academic IQ. Available at: https://academiq.org.ua.

American Councils (2021). Our Programs. Available at: https://americancouncils.org.ua/en/programs.

Boyko M. (2020) Academic integrity in the educational process of pedagogical university: managerial aspect. The Scientific Issues of Ternopil Volodymyr Hnatiuk National Pedagogical University. Series: Pedagogy, (2), 172-180.

NAQA (2021). The National Agency for Higher Education Quality Assurance (NAQA). Available at: https://en.naqa.gov.ua.

Stukalo, N., Dluhopolskyi, O. (2020). Educational programs accreditation in pandemic times: challenges for NAQA (Ukraine). Revista Romaneasca pentru Educatie Multidimensionala, 12(1Sup2), 167172.

TNPU (2021). Ternopil Volodymyr Hnatiuk National Pedagogical University. Available at: http://tnpu.edu.ua.

\section{ACKNOWLEDGEMENT}

This paper was supported by American Councils' project "Academic IQ" 2020-2022

Received for publication:

Revision received:

Accepted for publication:
06.06 .2021

24.06.2021

06.07.2021 


\section{How to cite this article?}

Style - APA Sixth Edition:

Boyko, M., \& Dluhopolskyi, O. (2021, July 15). Academic integrity in Ukrainian universities: Case of academic IQ project in TNPU. (Z. Cekerevac, Ed.) MEST Journal, 9(2), 1-6. doi:10.12709/mest.09.09.02.01

Style - Chicago Sixteenth Edition:

Boyko, Mariya, and Oleksandr, Dluhopolskyi. 2021. "Academic integrity in Ukrainian universities: Case of academic IQ project in TNPU." Edited by Zoran Cekerevac. MEST Journal (MESTE) 9 (2): 16. doi:10.12709/mest.09.09.02.01.

Style - GOST Name Sort:

Boyko Mariya and Dluhopolskyi Oleksandr Academic integrity in Ukrainian universities: Case of academic IQ project in TNPU [Journal] // MEST Journal / ed. Cekerevac Zoran. - Belgrade - Toronto : MESTE, July 15, 2021. - 2 : Vol. 9. - pp. 1-6.

Style - Harvard Anglia:

Boyko, M. \& Dluhopolskyi, O., 2021. Academic integrity in Ukrainian universities: Case of academic IQ project in TNPU. MEST Journal, 15 July, 9(2), pp. 1-6.

Style - ISO 690 Numerical Reference:

Academic integrity in Ukrainian universities: Case of academic IQ project in TNPU. Boyko, Mariya and Dluhopolskyi, Oleksandr. [ed.] Zoran Cekerevac. 2, Belgrade - Toronto : MESTE, July 15, 2021, MEST Journal, Vol. 9, pp. 1-6. 